\title{
Selected Approaches to Change Management and Logistics in Slovak Enterprises
}

\author{
L’ubica Simanová $^{*}$ and Renata Stasiak-Betlejewska² \\ ${ }^{1}$ University of Technical University in Zvolen, Department of Business Economics, T.G. Masaryk \\ 24, Zvolen, Slovakia; simanova@tuzvo.sk \\ ${ }^{2}$ Częstochowa University of Technology, Poland, Department of Production Engineering and \\ Safety, Faculty of Management, J.H. Dabrowskiego 69, 42-201Czestochowa; renata.stasiak- \\ betlejewska@wz.pcz.pl
}

\section{*Corresponding Author: L'ubica Simanová}

\begin{abstract}
Competitiveness and performance of businesses today depend on the ability to respond to changes, implementation of new methods, techniques and approaches in the management of business processes, business activities, and logistics. The aim of the article is to present the results of empirical research in the field of change management and implementation of selected approaches in the management of production processes in manufacturing enterprises and in the enterprises of the wood processing industry (WPI) enterprises in Slovakia which affect the level of return on equity (ROE).
\end{abstract}

Keywords: Process, change management, logistics, approaches, enterprises

\section{Introduction}

Continuous growth of competing claims and customer demands forces companies to analyses the attributes of their processes in detail, to use new methods, tools, techniques, and approaches to analysing, evaluating, managing, making changes and optimizing them. According to authors [1-3] coincide in the definition of the process as a set of interrelated activities with one or more types of inputs and form an output which has a certain value for the customer and represents a characteristic variable of process control. A similar opinion was expressed by Řepa, who claims that the business process is a sum of activities transforming inputs into a sum of outputs (goods or services) for other people [4].

Of these theoretical results it shows that the authors have a similar idea on that basis we will not further distinguish these concepts, as in the professional community are understood identically and without significant differences. Process management is focused on the causes of arising discrepancies, not on the final outputs. This type of management control is based on the idea that the cause of company's bad results is inefficient running of company processes where it is necessary to 
make them rationale and more effective, which will result in higher added value for the customer [5].

In order to change management, optimization and improvement of production processes, increasing organizational performance, achieve high productivity and efficiency in terms of process management is important in the selection of appropriate methods, tools and techniques. Business Process Management - BPM can be defined as a strategic approach to business management, in which using appropriate methods, techniques and tools of management processes for the purpose of achieving maximum business performance [6].

Change management in the enterprise can be seen as a project for which it is necessary to observe the following steps: defining targets and milestones, identify the person, their roles and responsibilities, determine the form and extent of communication, establishing a timetable. Successful change requires adaptation of methods, techniques, strategies and implementation tactics to specific history, culture, and people in the organization [7]. The change process is very complex, but there are models to make the change [8].

Methods of optimization, redesign and process reengineering are aimed at improving processes in an organization. Basically, they are divided into reengineering, business process reengineering (BPR), improvement, redesign, and continuous improvement methods based on quality management. Currently, the following improvement methods are used: Process Reengineering, Participatory Process Prototyping, and generally, it can be used to continuously improve the quality management methodology processes such as TQM (Total Quality Management), Deming PDCA, DMAIC, Six Sigma. The most used methods and approaches in process management of production, change management and in logistics by the authors [9-14] are as follows: Kanban, Just-In-Time, Optimized Production Technology - OPT, Method 5S, Lean Production, Kaizen, and Computer integrated production (CIM), and other.

Kanban represents so-called "free technology". According to authors [15-17] Kanban is a control mechanism of material flow, which controls the appropriate quality and production time needed products. The essence of the concept lies in the fact that parts and materials should be delivered at precisely the moment when the production process needs.

The philosophy of Just-In-Time (JIT) can be used between a numbers of undertakings in relation supplier-customer. Storage costs are passed on to the supplier, but he is confident that he will sell his production. JIT is also applied within one enterprise between individual centres based on the principle of tension [18]. 
Just as the name Just-In-Time suggests, this philosophy governs material flows to create zero supplies on the buyers' side. JIT objectives are often referred to as zero defects: zero set-up time, zero inventories, zero handling, zero breakdowns, zero lead time and lot size of one [19].

$\boldsymbol{O P T}$ - Optimized Production Technology according to authors [20,21] resulting bottlenecks have a significant impact on the production process. There is a push - pull principle applied here.

Undoubtedly it represents a successful system of planning and production management. It is one of the representatives of the groove with centralized systems of planning and production management.

Method 5 S - It is recommended to implement it throughout the enterprise, including manufacturing staff who, after thorough training, will be able to eliminate unnecessary activities from processes, to prioritize and to observe them, to save work equipment before the end of each shift to the designated place to avoid losses due to non-optimized deposit in the workplace [22,23].

Method Keizen - will be introduced at all levels of government and in all production and nonproduction processes of the company. In process improvement should be involved every single employee of the company. Through improvement proposals of employees is expected to increase process performance. Every employee has the opportunity to present its proposal for improvements to be assessed and then after evaluating the benefits financially assessed. This is consistent with authors [24-27]. Author [28] adds that Kaizen promotes process-oriented thinking because, to improve the results, processes need to be improved. The failure of efforts to achieve the intended results is a failure of the process.

Authors [18,29], say that Lean production report the following benefits from the implementation of lean manufacturing tools: double productivity, reducing inventory by $90 \%$, reducing defective products and waste by half, launching a new product faster and a wider range of products and variants at a small additional cost.

Computer integrated production (CIM) represents a change not only in the production management system but throughout the structure of the enterprise. It involves the use of information technology in all manufacturing and engineering activities, from concept and product design to shipping, to reduce material and energy demands, increase labour productivity, reduce inventory, shorten production and production times, increase time and power utilization production facilities and increase product quality [12]. Enterprise Resource Planning (ERP) is a term for complex enterprise software that is used to manage corporate resources [26]. 


\section{Data and Methods}

The questionnaire method was the primary method of primary quantitative research. The aim of the research was to determine the status of change management for reasons of financial performance, use of methods and approaches in process management and change management in Slovak enterprises. The enterprises from selected industrial branches of Slovak republic have been set as the research subjects.

The first database of enterprises comprised the data of the Statistical Office of the Slovak Republic, which was subsequently verified by Internet databases in order to select existing companies. The core sample or population size $(\mathrm{N})$ of the survey was a sample of 2525 enterprises sent online by a questionnaire. A representative sample (n) is represented by 524 enterprises, which is the number of completed questionnaires. The questionnaire consists of 5 general, classification questions and 30 business-area management issues. The questionnaire was published online and the data collection was in the first half of year 2017. Answers from the questionnaire have been processed and evaluated by chosen statistical method: descriptive statistics, contingent method, and Chi squared test.

\section{Results}

An important part of the research were general information about the investigated companies. Subsequently, questions were analysed on the use of selected approaches to production control, change management, and logistics.

\subsection{Results of General Questionnaire Research}

General questionnaire surveys aimed at determining the average number of employees, company ownership and return on equity (ROE) are shown in the absolute figures in Table 1. When analysing general research, we report the results in the category of all enterprises, manufacturing enterprises and WPI enterprises.

Table 1 shows that most enterprises employ between 0 and 10 employees, $45.23 \%$ for all enterprises, $36.51 \%$ for manufacturing enterprises and $45.12 \%$ for WPI enterprises, which shows that production is predominantly concentrated to small businesses. Research results showed that after 7.30\% of WPI enterprises employing 51-250 employees and more than 250 employees, the range from $13.17 \%$ to $17.56 \%$ for all enterprises and manufacturing enterprises.

The overwhelming majority of enterprises were included in a group whose ownership is net domestic capital, up to $70.80 \%$ of the total of 524 enterprises. Over $70 \%$ of manufacturing enterprises and WPI enterprises are equipped with net domestic capital. Enterprises with net foreign 
capital accounted for 5.34\% overall, manufacturing enterprises 5.29\%, and WPI enterprises $14.63 \%$. All enterprises with dominant domestic capital reached $16.42 \%$ and manufacturing enterprises $18.52 \%$. For WPI enterprises, it was only $1.22 \%$. The prevailing foreign capital accounted for $7.44 \%$ of all enterprises, $3.17 \%$ of manufacturing enterprises and $4.88 \%$ of WPI enterprises.

Table 1 Basic characteristics of rated enterprises. Source: author

\begin{tabular}{lccc}
\hline Enterprises & All enterprises & $\begin{array}{c}\text { Manufacturing } \\
\text { enterprises }\end{array}$ & $\begin{array}{c}\text { WPI } \\
\text { enterprises }\end{array}$ \\
\hline $0-10$ employees & The number of employees & 37 \\
\hline $11-20$ employees & 237 & 69 & 21 \\
\hline $21-50$ employees & 65 & 29 & 12 \\
\hline $51-250$ employees & 74 & 31 & 6 \\
\hline Over 250 employees & 79 & 33 & 6 \\
\hline Together & 69 & 27 & $\mathbf{8 2}$ \\
\hline & $\mathbf{5 2 4}$ & $\mathbf{1 8 9}$ & 65 \\
\hline Net domestic capital & The ownership of enterprises & 12 \\
\hline Prevailing domestic capital & 371 & 138 & 1 \\
\hline Prevailing foreign capital & 28 & 10 & 4 \\
\hline Net foreign capital & 86 & 35 & 6 \\
\hline & 39 & 6 & 21 \\
\hline ROE $<0$ & ROE - Return on Equity & 13 \\
\hline $0 \%-2 \%$ & 44 & 11 & 26 \\
\hline $2 \%-4 \%$ & 127 & 45 & 13 \\
\hline $4 \%-7 \%$ & 126 & 42 & 3 \\
\hline $7 \%-10 \%$ & 115 & 52 & 23 \\
\hline Over $10 \%$ & 54 & 16 & \\
\hline
\end{tabular}

The ROE values of all enterprises, manufacturing enterprises and WPI enterprises by ROE are compared in the Fig. 1. In determining the amount of the value of return on equity (ROE), about $24 \%$ of all enterprises have been placed into groups with ROE of $0 \%$ to $2 \%$ and $2 \%-4 \%$. ROE from $7 \%$ to $10 \%$ was recorded in all enterprises, manufacturing enterprises and WPI enterprises ranging from $10.31 \%$ to $15.85 \%$ and a positive value above $10 \%$ in the range from $3.66 \%$ to $11.07 \%$. The negative ROE was reported by $8.40 \%$ of all enterprises, $5.82 \%$ of manufacturing enterprises and $7.32 \%$ of WPI enterprises.

On the basis of a comparison of the results of the questionnaire survey, we can conclude that all enterprises, manufacturing enterprises and WPI enterprises have the largest percentage of values ranging from $0 \%$ to $2 \%$, from $2 \%$ to $4 \%$ and from $4 \%$ to $7 \%$. Up to $31.71 \%$ of WPI enterprises had the largest exposure in the ROE range of $4 \%$ to $7 \%$. Wood processing enterprises accounted for the vast majority of the research are represented with up to 60 enterprises. The rest of the sample was represented by 18 furniture production companies, and 4 cellulosic compiler enterprises. When evaluating research results, we focused on manufacturing companies and WPI enterprises as a whole. 


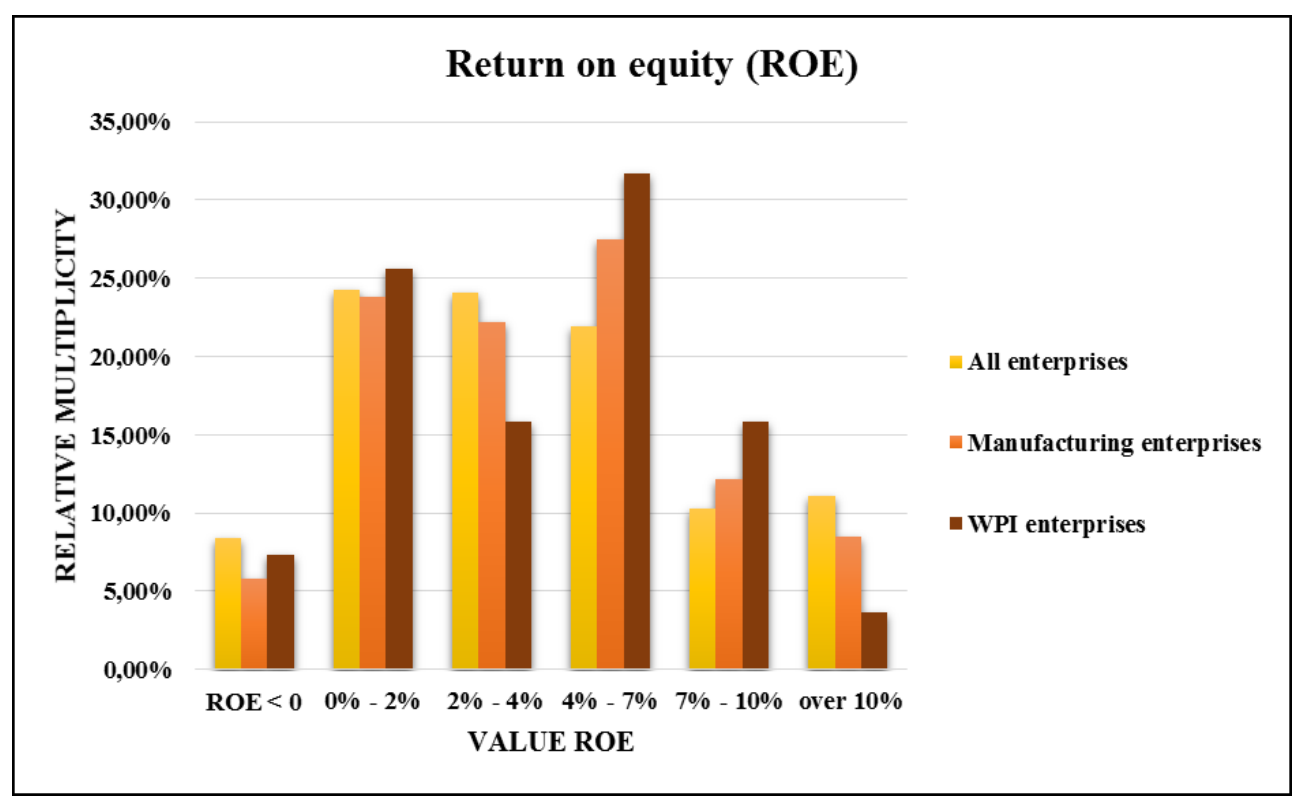

Fig. 1 Return on equity of all enterprises, manufacturing companies and WPI enterprises.

Source: author

\subsection{The Implementation of Production Management Approaches in Manufacturing Enterprises and WPI Enterprises}

The following section analyse results from the implementation of selection approaches process management, change management, and quality management, that affect the values of the ROE indicator in manufacturing enterprises and WPI enterprises. The analysis was performed using contingency tables in which two types of data can be seen. The first is the absolute number of answers to questions divided into groups based on the value of the ROE indicator. The second data is the percentage of responses based on the size of $\mathrm{n}$ in each group ROE detected using descriptive statistics, contingent method and Chi squared test.

Table 2 describes and analyses the relationship between the average number of responses in terms of production management approaches and the achieved ROE. Manufacturing enterprises that have achieved ROE values of $>10 \%$ have an average of nearly two options on this question, that is, approximately two approaches have been implemented. Manufacturing enterprises with negative ROE and with ROE ranging from $0 \%$ to $10 \%$ have 1 response, which means they have implemented one production management approach. The above results show that manufacturing enterprises with higher profitability are preparing for a change in production to a greater extent than enterprises with lower or with a negative ROE value. On the basis of the analysed results, we can say that the production enterprises that have implemented multiple approaches to the production management achieve a higher level of ROE. More precise preparation for change and its subsequent implementation also directly influences ROE on the basis of the above results. The most used approaches were Just in Time, CIM and others. 
Table 2 The contingency of implementing approaches to the management of production and the amount of ROE in manufacturing enterprises. Source: author

\begin{tabular}{lccccccc}
\hline \multirow{2}{*}{ Approaches } & \multicolumn{7}{c}{ Value ROE } \\
\cline { 2 - 9 } & $\mathbf{2 0 \%}$ & $\mathbf{0 \%} \mathbf{- 2 \%}$ & $\mathbf{2 \%} \mathbf{- 4 \%}$ & $\mathbf{4 \%} \mathbf{- 7 \%}$ & $\mathbf{7 \%} \mathbf{- 1 0 \%}$ & $\mathbf{1 0 \%}$ & $\mathbf{S U M}$ \\
\hline Kanban & 0 & 0 & 3 & 4 & 4 & 3 & 14 \\
\hline Just In Time & 3 & 13 & 10 & 14 & 10 & 5 & 55 \\
\hline OPT & 0 & 4 & 1 & 3 & 4 & 4 & 16 \\
\hline Lean Production & 0 & 3 & 3 & 4 & 2 & 2 & 14 \\
\hline Methods 5S & 2 & 4 & 4 & 12 & 2 & 5 & 29 \\
\hline CIM & 1 & 8 & 13 & 7 & 5 & 3 & 37 \\
\hline Systems ERP & 2 & 4 & 2 & 3 & 1 & 8 & 20 \\
\hline Other & 3 & 12 & 7 & 15 & 2 & 1 & 40 \\
\hline SUM & 11 & 48 & 43 & 62 & 30 & 31 & 225 \\
\hline Relative multiplicity \% & 4.89 & 21.33 & 19.11 & 27.56 & 13.33 & 13.78 & 100 \\
\hline $\begin{array}{l}\text { Average number of } \\
\text { responses per group }\end{array}$ & 1.00 & 1.07 & 1.02 & 1.19 & 1.30 & 1.94 & \\
\hline
\end{tabular}

Table 3 analyses the relationship between the production management approaches implemented by WPI enterprises and the value of the ROE indicator. From the results of the research shown in Table 3, it can be seen that the largest response at an average of 1.33 per group was achieved by a group of enterprises with a ROE of $>10 \%$, showing that the average of each third enterprise implemented two production management approaches.

Table 3 The contingency of implementing approaches to the management of production and the amount of ROE in manufacturing enterprises. Source: author

\begin{tabular}{lccccccc}
\hline Approaches & \multicolumn{7}{c}{ Value ROE } \\
\cline { 2 - 9 } & $\mathbf{0 0 \%}$ & $\mathbf{0 \%} \mathbf{- 2 \%}$ & $\mathbf{2 \%} \mathbf{- 4 \%}$ & $\mathbf{4 \%} \mathbf{- 7 \%}$ & $\mathbf{7 \% - 1 0 \%}$ & $>\mathbf{1 0 \%}$ & SUM \\
\hline Kanban & 0 & 0 & 0 & 2 & 1 & 0 & 3 \\
\hline Just In Time & 2 & 6 & 3 & 5 & 6 & 1 & 23 \\
\hline OPT & 0 & 2 & 0 & 1 & 1 & 0 & 4 \\
\hline Lean Production & 0 & 1 & 1 & 0 & 0 & 0 & 2 \\
\hline Methods 5S & 0 & 3 & 1 & 2 & 1 & 1 & 10 \\
\hline CIM & 2 & 1 & 6 & 5 & 2 & 1 & 16 \\
\hline Systems ERP & 1 & 1 & 0 & 2 & 0 & 1 & 4 \\
\hline Other & 0 & 6 & 2 & 9 & 3 & 0 & 21 \\
\hline SUM & 1 & 20 & 13 & 26 & 14 & 4 & 83 \\
\hline Relative multiplicity \% & 6.00 & 24.10 & 15.66 & 31.33 & 16.87 & 4.82 & 100 \\
\hline $\begin{array}{l}\text { Average number of } \\
\text { responses per group }\end{array}$ & 1.00 & 0.95 & 1.00 & 1.00 & 1.08 & 1.33 & \\
\hline
\end{tabular}

The most used approaches were Just in Time and CIM. From the results analysed, it can be concluded that WPI enterprises that have implemented more than one production management approach have achieved better ROE performance. 


\section{Discussion}

In order to evaluate the dependence between the implementation of selected production control approaches and the ROE indicator, two opposing hypotheses were established for both types of enterprises. The hypotheses were as follows:

H0: The implementation of selected production control approaches does not affect the ROE level achieved.

H1: The implementation of selected production management approaches influences the level achieved by the indicator

Using the Chi-quadrate of the test, the value obtained from the obtained data was determined by $\mathrm{p}$ for production plants at $\mathrm{p}=0.042755922$. The value obtained was less than 0.05 , allowing the assumption of the $\mathrm{H} 1$ hypothesis and rejection of $\mathrm{H} 0$. Based on the results, it can be stated that in the case of the production enterprises, the use of the ERP and CIM principle is the least affected by ROE. Kanban, Lean Production and Just in Time had the greatest impact on profitability, followed by Method 5S, OPT, CIM, and others. Based on the calculated $p$ value for WPIs, $p=0.692101387$, the hypothesis H1 was rejected. From the above results, it was found that in the WPI enterprises it was not possible to clearly confirm the dependence and influence of the implementation of the production management approach on the value of the ROE indicator.

Different results of research data analysis based on contingency tables and Chi-quadrate of the test can be attributed to various impacts, for example, misunderstanding of respondents' questions, ignorance of production management approaches, and a wide range of respondents did not have a primary interest in the issue.

\section{Conclusion}

Significant findings in this section of the research were to obtain general information about companies, information on the changes made and the reasons that led to them, and to involve management and staff in implementing changes in processes. By comparing the results with contingent method and Chi squared with each other, it is positive that, although the results of the analyses do not match and cannot be generalized, they provide us with a framework overview on perceptions of change management, the use of new approaches and methods in production management, change management, and logistics and their impact to improve the performance of businesses. 


\section{Acknowledgments}

We wish to thank project VEGA - Scientific Grant Agency of the Ministry of Education, Science, Research and Sport of the Slovak Republic (Project No.1/0286/16 and No. 1/0537/16).

\section{References}

[1] Krajčiová. M. (2010). Process control - 8 SMK principles. Retrieved September 24, 2018 Web: http://www.krajciova.sk/MANAZER/13_SMK_Zasady_V1.pdf

[2] Ludek, K. (2005). Economics of Process-Controlled Organizations. Prague: Oeconomica.

[3] Šmida, F. (2007). Implementation and Development of Process Management in the Company Prague: Grada.

[4] Repa, V. (2007). Business Processes: Process Management and Modeling. Prague: Grada.

[5] Marcineková, K. \& Sujová. A. (2015). The influence of the process control level on the enterprises' roe. In 9th International Scientific Conference on Business Economics and Management, 30 April - 2 May 2015 (pp. 290-295). Izmir, Turkey: ELSEVIER SCIENCE BV.

[6] Cienciala, J. (2011). Process-driven organization, creation, development, and process variabilit. Průhonice: Professional Publishing.

[7] Majtán, M. (2002). Project management. New trends in management. Bratislava: Economist.

[8] Rosenau, M. D. (2000). Project management. Prague: Computer Press.

[9] Dupal', A. \& Richnák, P. (2017). Current Trends and Improvements in Business Logistics. Economics, Finance and Business Management - 2017. Bratislava: EKONÓM (publishing house).

[10] Dupal', A. \& Brezina, I. (2006). Logistics in business management (p 326). Bratislava: SPRINT.

[11] Gejdoš, P. (2006). Six Sigma Method - a flexible system for improving corporate performance. Acta facultatis xylologiae XLWIII 2/2006. Zvolen: TU Zvolen.

[12] Gregor, M., Mičieta, B., Kosturiak, J., Bubeník, P. \& Růžička, J. (2000). Dynamic Planning and Production Management. Žilina: University in Žilina.

[13] Kavan, M. (2002). Manufacturing and Operations Management. Prague: Grada Publishing.

[14] Rašner, J. \& Rajnoha, R. (2006). Business Process Management Tools. Zvolen: Technical University of Zvolen. 
[15] Graves, R.J., Konopka J. M. \& Milne, R. J. (2007). Literature review of material flow control mechanisms. Production Planning \& Control (pp. 395-403). Web: https://www.tandfonline.com/doi/abs/10.1080/09537289508930296

[16] Lambert, D.M., Stock J.R. \& Ellram L. (2000). Logistics. Prague: Computer Press.

[17] Sixta, J. (2007). Controlling material flow through logistics (pp. 37). Škoda Auto College, SAU working papers. Mladá Boleslav.

[18] Tomek G. \& Vavrova V. (2001). Production Management. Prague: Grada.

[19] Basl, J. \& Blažíček R. (2012). Enterprise Information Systems: Enterprise in the Information Society. Prague: Grada.

[20] Feylizadeh, M. R. \& Bagherpour, M. (2011). Application of Optimization Techniques in Production Planning Context: A Review and Extension. International Journal of Manufacturing Systems, 1 (1), (pp. 1- 8).

[21] Heizer, J. H. (1992). Production and operations management: Strategies and tactics. Boston: Allyn and Bacon International.

[22] Mašín, I. \& Vytlačil, M. (2000). TPM: Management and Practical Deployment. Liberec: Institute of Industrial Engineering.

[23] Sarkar, D. (2006). 5S for Service Organizations and Offices. Milwaukee, USA: ASQ Quality Press.

[24] Čierna, H. \& Sujová, E. (2016). Application of modern QMS - KAIZEN management system. Retrieved September 18, 2018, from http://www.mmscience.eu.

[25] Imai, M. (2005). Gemba Kaizen - Quality Management and Improvement in the Workplace. Brno: Computer Press.

[26] Košturiak, J. \& Frolík, Z., 2006. Slim and innovative enterprise. Modern management (p. 240). Prague: Alfa Publishing, s.r.o.

[27] Košturiak, J. (2010). Kaizen: the proven practice of Czech and Slovak enterprises. Brno: Business books (Computer Press).

[28] Imai, M. (2004). Kaizen: a method of introducing more efficient and flexible production in the enterprise. Brno: Business books, Computer Press.

[29] Womack, J. P. \& Jones, D. T.(2003). Lean Thinking. New York: Free Press. 